\title{
Direction of Sexual Interest in Students and the Existence of Families in Their Development
}

\author{
Yarmis Syukur ${ }^{1, *}$, Isna Tani ${ }^{1}$, Triave Nuzila Zahri ${ }^{1}$, Khadijah Lubis ${ }^{1}$ \\ ${ }^{1}$ Department of Guidance and Counseling, Faculty of Education, Universitas Negeri Padang, Padang, Indonesia \\ *Email: yarmissyukur@fip.unp.ac.id
}

\begin{abstract}
When the formation of self-identity reaches the peak of adolescence can experience sexual identity disorder. The development of cases of LGB perpetrators among students who are at the stage of late adolescent development is an indication of the disruption of the formation of adolescent self-identity. One reason is that the education system in the family does not work well. This study aims to explain the direction of student sexual attraction and the existence of the family in preventing LGB among students. The results of the study showed that the sexual orientation of students was in a good category, so prevention efforts were needed so as not to fall prey to LGB behavior that was increasingly developing among the millennial generation
\end{abstract}

Keywords: sexual orientation, $L G B$, family

\section{INTRODUCTION}

Findings Students are individuals who enter the period of development of late adolescents with an age range of 1822 years. In late adolescence there were several developmental tasks. Among them must have the ability to foster relationships with peers who are the same or different sex, the ability to carry out social roles according to gender and have a set of values and ethical behavior [1]. Formation of identity reaches its peak in late adolescence and will continue throughout the human life span [2]. Teenagers are expected to have discovered sexual orientation or the direction of sexual attraction. In essence students have an interest in the opposite sex. Students who cannot achieve their developmental tasks can experience disturbed daily effective life (KES-T). Among other things, gender identity disorder and sexual orientation are increasingly sticking to the millennial generation.

These disorders are better known as Lesbian, Gay, Bisexual (LGB). LGB is a deviant behavior and contradicts the noble values of Pancasila [3]. LGB behavior is a "trend" among millennial generations so that it can disrupt the achievement of its development tasks.

As many as $60 \%$ of the LGB population in the world are young people [4]. The second highest number of LGB participants in West Sumatra is students [5]. This shows that students are very vulnerable to LGB behavior.

LGB is the impact of promiscuity in adolescence and the uncontrolled influence of foreign culture [6]. The LGB phenomenon invites curiosity and fosters a sense of curiosity in adolescents. LGB is also a sexual deviation that is contrary to religious values, politeness and moral values.
LGB is not caused by genes or heredity, but is a disorder that arises due to certain factors. For example the family environment, social environment, biological conditions, and psychological conditions [7]. Biological conditions in the form of hormone influences can make individuals have sexual disorientation. Individuals who have received or seen acts of domestic violence, the treatment of parents who do not fit their child's gender also causes a person to become an LGB actor. Associations in the community, campus and workplace can trigger LGB behavior. Individuals who have experienced sexual abuse or feel pressured by their own gender can also fall into LGB behavior.

Socio-emotional conditions in the family are one of the reasons why students fall into LGB behavior and the family is the place to get the first and foremost education. Therefore, the role of family members in preventing LGB behavior in students is very necessary.

\section{METHOD}

This research is a quantitative descriptive study. Respondents in this study were 132 students who were undergoing studies at one of the state universities in the city of Padang. Samples were taken using purposive sampling technique. The data collection tool in the form of a scale adapted from The Lesbian, Gay \& Bisexual Identity Scale (LGBIS) developed through eight aspects, namely acceptance concerns, concealment motivation, identity uncertainty, internalized difficult homonegativity processes, identity superiority, identity affirmation, identity centrality [8]. Data were analyzed using descriptive statistics 


\subsubsection{Description of Sexual Orientation on the Aspect of Identity Uncertainty}

\subsection{Description of Student Sexual Orientation}

\subsubsection{Description of Sexual Orientation on the Acceptance Aspects of Concerns}

A description of the student's sexual orientation in the acceptance concerns aspect can be seen in the following diagram.

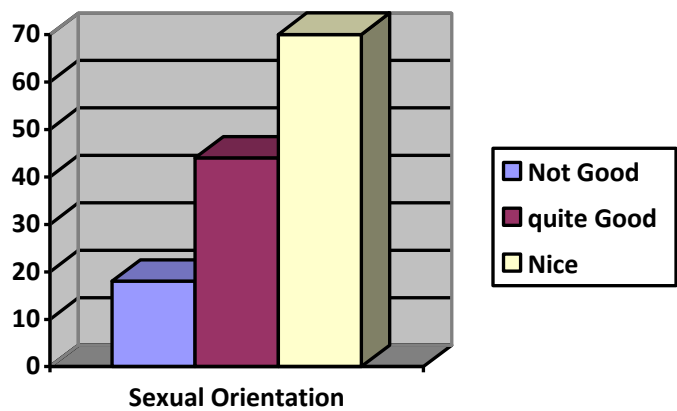

Based on the data in Diagram 1, sexual orientation in the acceptance concern aspect is $14 \%$ in the bad category, $33 \%$ in the pretty good category and $53 \%$ in the good category.

\subsubsection{Description of Sexual Orientation on the Aspect of Concealment Motivation}

Based on the data processing criteria used can be described sexual orientation in the aspect of concealment motivation, as follows.

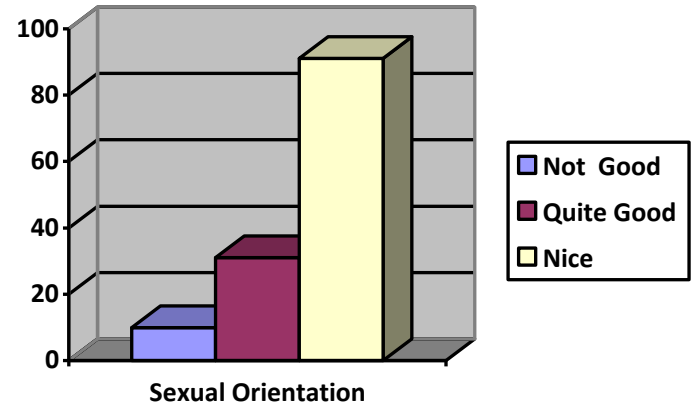

Based on data in Diagram 2, $8 \%$ of sexual orientation in the concealment motivation aspect is in the bad category, $23 \%$ is in the pretty good category and $69 \%$ is in the good category
A description of the student's sexual orientation in the aspect of Identity Uncertainty can be seen in the following diagram.

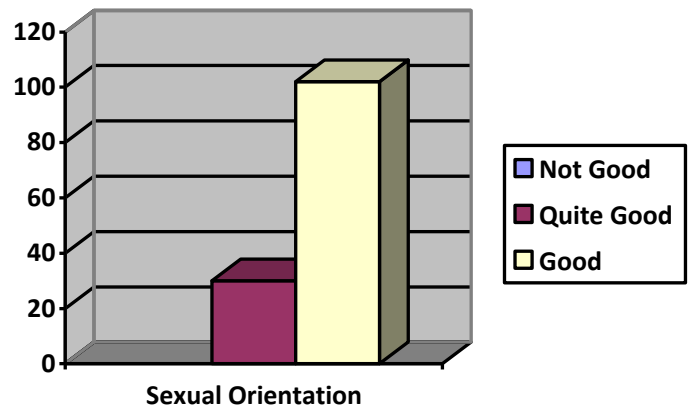

Based on the data in Diagram 3, it is seen that sexual orientation in the identity uncertainty aspect is $0 \%$ in the bad category, $23 \%$ in the pretty good category and $77 \%$ in the good category.

\subsection{Description of Sexual Orientation on the Aspects of Internalized Homonegativity}

The description of a student's sexual orientation on aspects of Internalized Homonegativity can be seen in the following diagram.

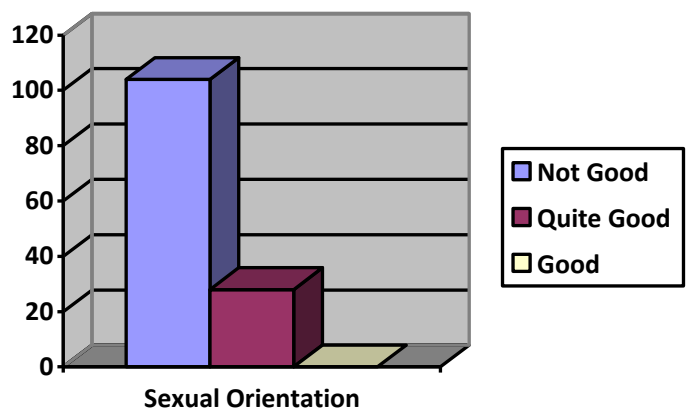

Based on the data in Diagram 4, it appears that sexual orientation in the aspects of Internalized Homonegativity as much as $79 \%$ is in the bad category, $21 \%$ is in the pretty good category and $0 \%$ is in the good category.

\subsubsection{Description of Sexual Orientation on Aspects of the Difficult Process}

A description of the student's sexual orientation in the Difficult Process aspect can be seen in the following diagram. 


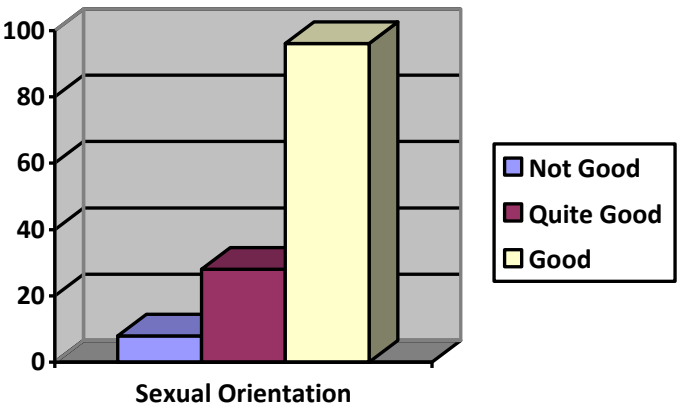

Based on the data in Diagram 5, it is seen that sexual orientation in the Difficult Process aspect as much as 6\% is in the bad category, $21 \%$ is in the pretty good category and $73 \%$ is in the good category.

\subsubsection{Description of Sexual Orientation on Aspects of Identity Superiority}

A description of the student's sexual orientation in the aspect of Identity Superiority can be seen in the following diagram.

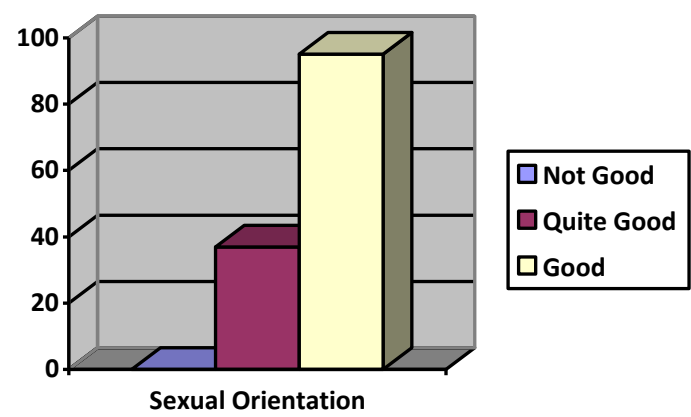

Based on the data in Diagram 6, it was seen that sexual orientation in the aspect of Identity Superiority was $0 \%$ in the bad category, $28 \%$ in the pretty good category and $72 \%$ in the good category.

\subsubsection{Description of Sexual Orientation on the Identity Affirmation Aspect}

A description of the student's sexual orientation in the Identity Affirmation aspect can be seen in the following diagram.

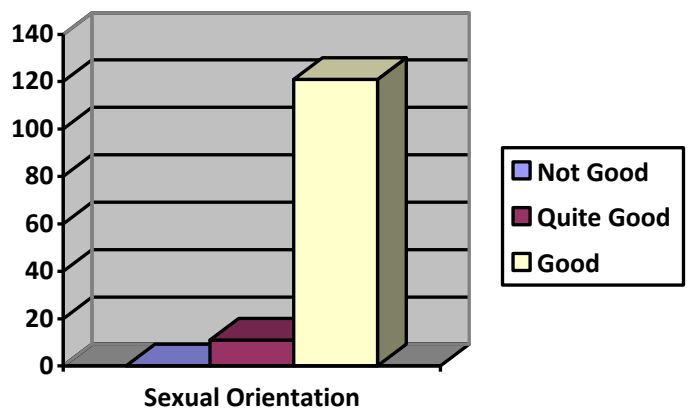

Based on the data in Figure 7, it was seen that sexual orientation in the Identity Affirmation aspect was $0 \%$ in the bad category, $8 \%$ in the pretty good category and $92 \%$ in the good category.

\subsubsection{Description of Sexual Orientation on the Identity Centrality Aspect}

A description of the student's sexual orientation in the aspect of Identity Centrality can be seen in the following diagram.

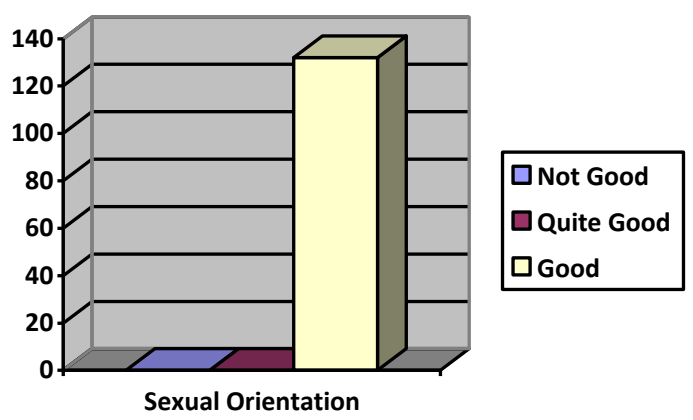

Based on the data in Diagram 8, sexual orientation in the Identity Centrality aspect is $0 \%$ in the bad category, $0 \%$ in the pretty good category and $132 \%$ in the good category. 


\subsection{Differences in Student Sexual Orientation}

Table 1 Test Results for Differences in Sexual Orientation Viewed from Gender

\begin{tabular}{|c|c|c|c|c|c|c|}
\hline \multicolumn{2}{|c|}{$\begin{array}{l}\text { Independent } \\
\text { Samples Test }\end{array}$} & $\mathbf{F}$ & Sig. & $\mathbf{t}$ & df & $\begin{array}{l}\text { Sig. } \\
(2- \\
\text { tailed })\end{array}$ \\
\hline \multirow{2}{*}{$\begin{array}{l}\text { Orientasi } \\
\text { Seksual }\end{array}$} & $\begin{array}{l}\text { Equal } \\
\text { variances } \\
\text { assumed }\end{array}$ & .143 & .706 & $\begin{array}{l}- \\
.109\end{array}$ & 130 & .914 \\
\hline & $\begin{array}{l}\text { Equal } \\
\text { variances } \\
\text { not } \\
\text { assumed }\end{array}$ & & & $\begin{array}{l}- \\
.110\end{array}$ & 91.285 & .914 \\
\hline
\end{tabular}

Based on Table 1 it can be seen the significance of the test results of differences in student sexual orientation of 0.914 greater than 0.05 . This shows that there is no

\section{DISCUSSION}

\subsection{Description of Student Sexual Orientation}

Sexual orientation shows the direction of an individual's emotional and sexual attraction to the opposite sex or same-sex [9]. Based on the results of the research, students' sexual orientation is in a good category. This shows that students have a reasonable interest in fellow students.

The development of student sexual orientation needs to be considered so as not to fall prey to LGB behavior. LGB behavior is an action to foster romantic relationships with same-sex and the opposite sex [10]. This behavior can interfere with the formation of student identity. In the formation of self-identity the role of the family is very dominant. In order to avoid LGB behavior, especially parents or caregivers where students live during their education, they need to provide appropriate direction or treatment so that their true identity is formed.

Apart from the family, students also need to be briefed in formal education to form the right self identity. One of them is the Guidance and Counseling service to develop students' abilities in fostering effective social relations with same-sex or different sexes and achieving selfidentity [11]. Marjohan (2013) argues that organizing guidance and counseling services with the foundation for effective daily living is one of the steps that can be taken to prevent LGB. BK services are carried out in the development of effective individual independence and life, increasing self-competence, and applying moral values and self-control [4].

Another solution that can be implemented to prevent LGB behavior is to increase the role of the family in maintaining the function of youth morality. If family difference in sexual orientation between male and female students.

conditions are not conducive, poor communication, lack of parental control, lack of planting moral values can lead to falling into adolescence in LGB conditions [13].

\subsection{The Existence of Families in Preventing the Behavior of LGB Students}

Prevention of LGB behavior can be done by creating family resilience, harmony in the family, proper parenting, and providing good education [14]. Sex education in preventing LGB behavior is mainly given by parents. Sex education should be given and started from the family environment, because sex education is part of family education [15]. Parents are the main source of sex education for adolescents and sex education is adjusted to the level of child development [16]. Sex education to foster a sense of responsibility for the value of biological sex, gender and sexual orientation is important to give to children and adolescents.

Students' understanding and knowledge of sexual orientation has basically grown in life in the family environment [17]. Family sex education is needed so students do not fall prey to deviant behavior. Therefore, the role of the family is needed to prevent student LGB behavior. Family is one of the important factors in preventing LGB behavior. Families can act as providers of correct information about correct sexual behavior for adolescents. This information is related to changes and physical, mental, and emotional maturity developments related to sexual problems in adolescents. Families are expected to provide adequate information about appropriate sexual behavior to adolescents so that through information obtained by adolescents can control their sexual behavior including homosexuality [18]. Adolescents need to get as much information as possible about the correct sexual behavior of their families so that 
teens do not seek information from other sources that are not necessarily accurate.

In addition to providing information, the family also plays a role as a form of positive attitudes for adolescents. It is intended that adolescents do not fall into negative association and deviant sexual orientation. Families need to provide proper education to adolescents to avoid deviant sexual behavior [18].

\section{ACKNOWLEDGMENT}

The development of LGB behavior deviations among the nation's next generation needs to be prevented. Based on this research, it is expected that each family member plays a role in forming student self-identity through various educational methods. In the future therapy can also be developed to prevent LGB behavior.

\section{REFERENCES}

[1] K. Z. Saputro, "Memahami Ciri dan Tugas Perkembangan Masa Remaja,” Apl. J. Apl. Ilmu Ilmu Agama, vol. 17, no. 1, pp. 25-32, 2017.

[2] R. E. Mastuti, R. D. Winarno, and L. W. Hastuti, "Pembentukan Identitas Orientasi Seksual Pada Remaja Gay," Prediksi, vol. 1, no. 2, p. 194, 2012.

[3] W. Setiawan and Y. D. Sukmadewi, “"Peran Pancasila pada Era Globalisasi” Kajian terhadap Pancasila dan Fenomena LGBT (Lesbian, Gay, Bisexual, Transgender) di Indonesia," J. Din. Sos. Budaya, vol. 19, no. 1, pp. 126-147, 2017.

[4] Z. Ardi, F. M. Yendi, and R. D. Febriani, "Fenomena LGBTQ dalam Perspektif Konseling dan Psikoterapi: Realitas dan Tantangan Konselor," J. Educ. J. Pendidik. Indones., vol. 4, no. 2, p. 77, 2018.

[5] Alfitri, K. Welong, Y. Media, and W. Wahyudi, Studi Pemetaan Perilaku LGBT di Provinsi Sumatera Barat. Padang: Balitbang Sumatera Barat, 2018.

[6] T. Ermayani, "LGBT dalam Perspektif Hukum Islam," J. Humanika, vol. 17, no. 2, pp. 147-168, 2017.

[7] Z. Aryanti, "Faktor Resiko Terjadinya LGBT pada Anak dan Remaja," Nizham-Jurnal Stud. Keislam., vol. 4, no. 1, pp. 5-24, 2016.

[8] J. J. Mohr and M. S. Kendra, "Revision and Extension of a Multidimensional Measure of Sexual
Minority Identity: The Lesbian, Gay, and Bisexual Identity Scale," J. Couns. Psychol., vol. 58, no. 2, pp. 234-245, 2011.

[9] W. Rahardjo, “Sikap Akan Respon terhadap Identitas Sosial Negatif dan Pengungkapan Orientasi Seks pada Gay," J. Psikol., vol. 1, no. 1, pp. 90-96, 2007.

[10] S. Siyoto and D. K. Sari, “Analisis Faktor-faktor yang Berhubungan dengan Perilaku Homoseksual (Gay) di Kota Kediri," J. Str., vol. 3, no. 1, pp. 68-75, 2014.

[11] L. Marlynda, "Upaya Guru Bimbingan Konseling dalam Mengatasi Perilaku Menyimpang Berpacaran Siswa," J. Edukasi J. Bimbing. Konseling, vol. 3, no. 1, pp. 40-57, 2017.

[12] M. Marjohan, "Pengembangan Internal Locus of Control dalam Pelayanan Konseling dan Implikasinya terhadap Perbedaan Budaya Klien,” J. Konseling dan Pendidik., vol. 1, no. 2, p. 136, 2013.

[13] N. Sumadi, Suriadi, and W. Kirana, "Pengalaman Traumatik dan Komunikasi Keluarga Efektif dalam Pembentukan Pribadi Penyimpangan Seksual Lesbian," Fak. Kedokt. Univ. Tanjungpura Pontianak, vol. 1, no. 1, 2013.

[14] E. Yanuarti, "Pola Asuh Islami Orang Tua dalam Mencegah Timbulnya Perilaku LGBT Sejak Usia Dini," Cendekia J. Kependidikan Dan Kemasyarakatan, vol. 17, no. 1, p. 57, 2019.

[15] Maryatun and W. Purwaningsih, "Hubungan Pengetahuan dan Peran Keluarga dengan Perilaku Seks Pranikah pada Remaja Anak Jalanan di Kota Surakarta," Gaster, vol. 9, no. 1, pp. 22-29, 2012. [16] E. Pratama, S. Hayati, and E. Supriatin, "Hubungan Pengetahuan Remaja Tentang Pendidikan Seks dengan Perilaku Seks Pranikah pada Remaja di SMA Z Kota Bandung," J. Ilmu Keperawatan, vol. II, no. 2, pp. 149-156, 2014.

[17] M. Hariyani, M. Mudjiran, and Y. Syukur, "Dampak Pornografi Terhadap Perilaku Siswa dan Upaya Guru Pembimbing untuk Mengatasinya," Konselor, vol. 1, no. 2, pp. 1-8, 2012.

[18] L. Rinta, "Pendidikan Seksual dalam Membentuk Perilaku Seksual Positif pada Remaja dan Impllikasinya terhadap Ketahanan Psikologi Remaja," J. Ketahanan Nas., vol. 21, no. 3, pp. 163-174, 2015. 